\title{
THE UTILIZATION OF INTRAVENOUSLY INJECTED SALT IN NORMALS AND IN PATIENTS WITH CUSHING'S SYNDROME BEFORE AND AFTER ADMINISTRATION OF DESOXY- CORTICOSTERONE ACETATE ${ }^{1}$
}

\author{
BY LOUIS J. SOFFER, GERSON LESNICK,2 S. ZELIG SORKIN,8 \\ HARRY H. SOBOTKA, AND MILDRED JACOBS \\ (From the Medical Services of Dr. George Baehr and Dr. Eli Moschcowitz, and the Depart- \\ ment of Chemistry of the Labortories of The Mount Sinai Hospital, New York City)
}

(Received for publication May 22, 1943)

The following report deals with the utilization of intravenously injected salt, before and after the injection of desoxycorticosterone acetate, in normal individuals and in patients with "Cushing's syndrome."

We observed that, in normal individuals, the intravenous injection of salt following the intramuscular injection of a single dose of desoxycorticosterone acetate resulted in a considerable retention of injected salt, above that seen prior to the injection of the hormone. In contrast to these results, the patients with Cushing's syndrome showed a pronounced sodium chloride diuresis.

It is interesting to note that Kuhlmann and his coworkers (1) and Ragan and his group (2) reported the production of a diabetes insipidus-like condition following the daily intramuscular administration of 20 to $25 \mathrm{mgm}$. of desoxycorticosterone acetate to normal dogs. These observations were confirmed by Mulinos and his coworkers (3), even though this latter group employed considerably smaller dosages of the hormone.

\section{METHOD}

All tests were conducted according to the following standard routine: The patients were permitted no food throughout the period of observation and no fluid after 7 P.M., the night before. At 6 A.M. on the morning of the studies, the patient was asked to void and the urine discarded. He was then given $500 \mathrm{cc}$. of water to drink at one time, and all the urine voided was collected over a 3-hour period to 9 A.M., carefully labeled and set aside. At 9 A.M., $200 \mathrm{cc}$. of 5 per cent saline (10 grams of salt) were injected intravenously and the urine voided during the next 3 hours, to $12 \mathrm{M}$., was similarly collected

\footnotetext{
1 Aided by a grant from the Ciba Pharmaceutical Company, Summit, N. J. The desoxycorticosterone acetate (Percorten) was generously supplied by Mr. Robert C. Mautner of the Ciba Pharmaceutical Company.

2 Lieutenant, M. C., A. U. S.

8 Moses Heinemann Fellow.
}

and labeled. Two days later, the same procedure was repeated, except that the patient was injected the previous evening at 10 P.M. with $10 \mathrm{mgm}$. of desoxycorticosterone acetate, intramuscularly. The urine volume of each period was carefully measured and sodium and chloride determinations were made on each specimen. Sodium was determined according to the method of Butler and Tuthill (4), and chlorides according to the method of Van Slyke (5). The total urinary sodium and chloride ions excreted during the 6 A.M. to 9 A.M. period were subtracted from those excreted between 9 A.M. and $12 \mathrm{M}$. (period after the intravenous injection). The difference represents the excess over the basal excretion of these ions. This figure in milliequivalents, divided by 171 (i.e. milliequivalents in 10 grams of sodium chloride), yields the fraction of the injected ions excreted $(\mathrm{NaC}$ and $\mathrm{Cl}_{\mathrm{C}}$ ). The comparison of the results obtained during the control period and that after the injection of desoxycorticosterone acetate showed the percentage of increased retention resulting from the use of the hormone.

\section{RESULTS}

In Table I are presented the results obtained in the normal individuals and in the patients with Cushing's syndrome. It will be seen that, with the exception of one instance, all the normals showed a considerable increase in the percentage of injected salt retained after the injection of desoxycorticosterone. The patients with Cushing's syndrome, on the other hand, retained a much smaller percentage of the injected salt after administration of the hormone than they did during the corresponding control studies. In general, the urinary excretion of the sodium and chloride ions ran parallel to one another, both during the control studies and after the injection of the hormone.

\section{DISCUSSION}

The following tentative explanation of the contrasting results obtained in normal individuals and in patients with Cushing's syndrome is of- 
TABLE I

\begin{tabular}{|c|c|c|c|c|c|c|c|c|c|c|c|c|}
\hline \multicolumn{5}{|c|}{ Control } & \multicolumn{4}{|c|}{$\begin{array}{l}\text { After injection of } 10 \mathrm{mgm} \text {. of } \\
\text { desoxycorticosterone acetate }\end{array}$} & \multicolumn{4}{|c|}{ Excretion } \\
\hline $\begin{array}{l}\text { Nor- } \\
\text { mals }\end{array}$ & $\begin{array}{c}6 \text { to } \\
9 \\
\text { A.M. }\end{array}$ & $\begin{array}{l}9 \text { to } \\
12 \\
\text { A.M. }\end{array}$ & $\begin{array}{c}\text { In- } \\
\text { jected } \\
\mathrm{Na} \\
\text { ex- } \\
\text { creted } \\
\mathrm{Na}_{\mathrm{C}}\end{array}$ & $\begin{array}{l}\text { In- } \\
\text { jected } \\
\mathrm{Cl} \\
\text { ex- } \\
\text { creted } \\
\mathrm{Cl}_{\mathrm{C}}\end{array}$ & $\begin{array}{c}6 \text { to } \\
9 \\
\text { A.M. }\end{array}$ & $\begin{array}{l}9 \text { to } \\
12 \\
\text { A.M. }\end{array}$ & $\begin{array}{l}\text { In- } \\
\text { jected } \\
\text { Na } \\
\text { ex- } \\
\text { creted } \\
\mathrm{Na}_{\mathbf{D}}\end{array}$ & $\begin{array}{l}\text { In- } \\
\text { jected } \\
\mathrm{Cl} \\
\text { ex- } \\
\text { creted } \\
\mathrm{Cl}_{\mathbf{D}}\end{array}$ & $100 \frac{\left(N a_{C}-N a_{D}\right)}{N a_{C}}$ & $100 \frac{\left(\mathrm{Cl}_{c}-\mathrm{Cl}_{\mathrm{D}}\right)}{\mathrm{Cl}_{\mathrm{C}}}$ & $100 \frac{\left(\mathrm{Na}_{\mathrm{D}}-\mathrm{Na} \mathrm{a}_{\mathrm{C}}\right)}{\mathrm{Na}}$ & $100 \frac{\left(\mathrm{Cl}_{\mathrm{D}}-\mathrm{Cl}_{\mathrm{C}}\right)}{\mathrm{Cl}_{\mathrm{C}}}$ \\
\hline $\begin{array}{l}\text { S. B. } \\
\text { M. L. } \\
\text { A. B. } \\
\text { B. C. } \\
\text { H. R. } \\
\text { H. S. } \\
\text { R. O. } \\
\text { R. M. } \\
\text { W. } \\
\text { Z. } \\
\text { Y. F. } \\
\text { D. K. }\end{array}$ & $\begin{array}{l}c c . \\
245 \\
778 \\
170 \\
503 \\
710 \\
565 \\
250 \\
420 \\
235 \\
252 \\
26 \\
970\end{array}$ & $\begin{array}{l}c c . \\
190 \\
333 \\
170 \\
360 \\
270 \\
230 \\
152 \\
165 \\
284 \\
108 \\
83 \\
380\end{array}$ & $\begin{array}{c}\text { per cent } \\
4.9 \\
24.5 \\
12.6 \\
24.1 \\
19.3 \\
19.2 \\
3.7 \\
17.6 \\
10.5 \\
8.6 \\
0.2 \\
29.8\end{array}$ & \begin{tabular}{|c|} 
per cent \\
12.7 \\
32.3 \\
10.7 \\
27.4 \\
21.8 \\
25.1 \\
7.3 \\
17.2 \\
15.2 \\
5.7 \\
1.0 \\
34.5
\end{tabular} & $\begin{array}{r}c c . \\
304 \\
662 \\
192 \\
510 \\
500 \\
420 \\
335 \\
248 \\
316 \\
148 \\
27 \\
770\end{array}$ & $\begin{array}{r}c c . \\
125 \\
241 \\
132 \\
254 \\
260 \\
250 \\
150 \\
108 \\
126 \\
88 \\
34 \\
300\end{array}$ & $\begin{array}{r}\text { per cent } \\
2.7 \\
-1.2 \\
4.8 \\
15.8 \\
13.8 \\
-20.6 \\
5.6 \\
7.5 \\
1.5 \\
3.4 \\
0.1 \\
26.5\end{array}$ & $\begin{array}{r}\text { per cent } \\
8.8 \\
-2.6 \\
2.4 \\
16.1 \\
19.3 \\
-6.0 \\
13.8 \\
12.3 \\
-1.5 \\
4.1 \\
0.1 \\
30.8\end{array}$ & 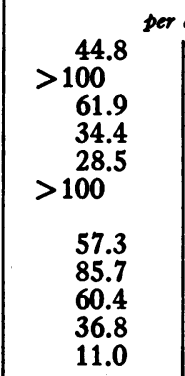 & $\begin{array}{c}30.6 \\
>100 \\
68.8 \\
41.2 \\
11.4 \\
>100 \\
\\
28.4 \\
>100 \\
28.0 \\
88.5 \\
10.7\end{array}$ & \multicolumn{2}{|c|}{ per cent } \\
\hline \multicolumn{13}{|l|}{$\begin{array}{l}\text { Cuugh- } \\
\text { ing's } \\
\text { syn- } \\
\text { drome }\end{array}$} \\
\hline $\begin{array}{l}\text { E. S. } \\
\text { A. P. } \\
\text { A. P. } \\
\text { E. G. } \\
\text { T. S. } \\
\text { J. S. }\end{array}$ & $\begin{array}{r}245 \\
378 \\
63 \\
650 \\
255 \\
342\end{array}$ & $\begin{array}{l}190 \\
336 \\
600 \\
250 \\
190 \\
130\end{array}$ & $\begin{array}{r}26.7 \\
8.9 \\
39.5 \\
11.8 \\
10.8 \\
5.9\end{array}$ & $\begin{array}{r}32.0 \\
9.1 \\
39.1 \\
12.2 \\
14.8 \\
5.9\end{array}$ & $\begin{array}{l}297 \\
380 \\
265 \\
418 \\
274 \\
315\end{array}$ & $\begin{array}{l}950 \\
418 \\
900 \\
238 \\
365 \\
124\end{array}$ & $\begin{array}{r}70.3 \\
19.8 \\
59.7 \\
17.3 \\
39.6 \\
7.8\end{array}$ & $\begin{array}{r}59.8 \\
19.5 \\
60.0 \\
19.0 \\
36.1 \\
9.1\end{array}$ & & & $\begin{array}{r}163.2 \\
122.4 \\
51.1 \\
46.6 \\
280.7 \\
32.2\end{array}$ & $\begin{array}{r}87.0 \\
114.2 \\
53.4 \\
55.7 \\
143.8 \\
54.2\end{array}$ \\
\hline
\end{tabular}

The percentages of injected $\mathrm{Na}$ and $\mathrm{Cl}$ excreted $\left(\mathrm{NaC}_{\mathrm{C}}\right.$ and $\mathrm{Cl}_{\mathrm{C}}$ ) were computed as follows: The total $\mathrm{Na}$ and $\mathrm{Cl}$ output for the 6 to 9 A.M. period was subtracted from that of the 9 to 12 period. The resulting amount is expressed in milliequivalents, divided by 171 (equals number of milliequivalents $\mathrm{Na}$ and $\mathrm{Cl}$ contained in $10 \mathrm{grams} \mathrm{NaCl}$ ), and multiplied by 100 to yield percentages. The same procedure was followed after the injection of hormone, yielding the percentage $\mathrm{Na}_{\mathbf{D}}$ and $\mathrm{Cl}_{\mathbf{D}}$.

fered. It is interesting to note the infrequency with which edema occurs in the normal animal following treatment with desoxycorticosterone acetate, as contrasted to the bilaterally adrenalectomized one so treated (2). We have noted a similar phenomenon in the treatment of patients with Addison's disease and in the experimental use of the hormone in individuals who have no evidence of adrenal cortical disease. The former are very much more prone to the development of edema following the use of the hormone. It would appear that some compensatory mechanism operates in animals and patients with intact adrenals that delimits the salt-retaining effect of the desoxycorticosterone. This is evidenced not only by the above findings, but also by the fact that patients with adrenal cortical tumors do not develop edema. In the presence of such tumors, one might expect that the increase in mass of adrenal cortical tissue, theoretically resulting in increased formation of salt-retaining hormone, would cause progressive edema. The fact that such edema does not occur would suggest several possibilities: (1) That the salt-retaining hormone is not formed in excess in these instances; (2) that excessive salt-retaining hormone formed is rapidly converted into another substance lacking salt-retaining effects; or (3) that the formation of excessive amounts of salt-retaining hormone stimulates the production of diuretic hormones, either in the adrenal itself or in the anterior lobe of the hypophysis. The results obtained in our studies would suggest that either or both of the last two possibilities operates. The conversion of the desoxycorticosterone into a non-salt-retaining hormone would at least seem theoretically possible in view of the close chemical similarity between desoxycorticosterone and other adrenal steroid hormones which have no salt-retaining effect, such as Corticosterone, or which actually 
expedite sodium and chloride excretion, such as 17-Hydroxycorticosterone.

\section{CASE REPORTS OF PATIENTS WITH CUSHING'S SYNDROME}

E. S. Female, age 37. This patient was well until $21 / 2$ years ago, at which time she noticed a slight but definite decrease in visual acuity. One and one-half years ago, she developed large ecchymotic areas over the lower extremities, which have recurred at frequent intervals since. Six months ago, she noticed a change in the appearance of her face. Her face became round, puffy, plethoric, with coarsening of the features and marked hirsutism. During this period of time, she developed amenorrhea. On physical examination, she was found to be very obese. She had many purplish striae over the abdomen and large ecchymotic areas over the lower extremities. Pelvic examination failed to reveal any adnexal masses. The blood pressure was 154/114. Hemoglobin was 105 per cent; red blood cells, 5.4 million; white blood cells and differential were normal. The oral glucose tolerance test, employing 1.75 grams of glucose per $\mathrm{kgm}$. of body weight, yielded the following results: Control, 70 mgm. per cent ; 1/2 hour, 150; 1 hour, 250; 2 hours, 175 ; 3 hours, 210 ; 4 hours, 110 ; and 5 hours, $65 \mathrm{mgm}$. per cent. The serum cholesterol was 230 , calcium was 8.8, and inorganic phosphorous $2.9 \mathrm{mgm}$. per cent; phosphatase was $9.4 \mathrm{~K}-\mathrm{A}$ units, and chlorides, 115 m.eq. per L. Urine showed frequent traces of sugar. X-ray studies showed a normal sella, marked osteoporosis of the entire spine, and an old fracture of the left fifth rib in the anterior axillary line. Peri-renal insufflation revealed a mass on the left side, and, on operation, an adrenal cortical tumor the size of a small plum was removed.

A. P. Male, age 27 . In 1941 , the patient noticed a rapid gain in weight, swelling and redness of the face, thinning of the hair, polyuria, polydypsia, diminution in the size of the penis, and loss of libido. On physical examination, he was found to be an obese man with florid, buffalo-like facies, and marked purplish axillary and abdominal striae. The blood pressure was $178 / 104$. The blood hemoglobin was 91 per cent with 4.4 million red blood cells per c.mm. The white blood count and differential were normal. The urine showed a 4-plus sugar. The blood urea $\mathrm{N}$ was $11 \mathrm{mgm}$. per cent and sugar 200 . The serum cholesterol was 440 , esterified cholesterol 225 , calcium 10.1, inorganic phosphorous $2.7 \mathrm{mgm}$. per cent, and chlorides, 100 m.eq. per $\mathrm{L}$. The blood phosphatase was $19 \mathrm{~K}-\mathrm{A}$ units. The glucose tolerance curve was typically diabetic in character with a 2-hour rise to 410 mgm. per cent. The basal metabolic rate was -31 per cent. The visual fields showed slight temporal constriction of the peripheral fields. $\mathrm{X}$-rays of the skull and long bones were normal, but the lumbosacral spine showed moderate generalized osteoporosis with compression of the vertebral bodies. Peri-renal insufflation failed to reveal any adrenal masses.

E. G. Female, age 33. Ten months before admission to the hospital the patient developed amenorrhea which has persisted to date. During this period of time, she developed marked facial hirsutism, swelling, redness and roundness of the face, an acneform rash over the back, and gained 12 pounds in weight. The physical examination revealed a short, obese, plethoric-looking woman with a marked kyphosis. There were deep reddish striae over the left flank, and the fingers and toes showed some acrocyanosis. The pelvic examination was negative. The blood pressure was 160/100; hemoglobin, 100 per cent; red blood cells, 5.2 millions per c.mm., and the urine was negative for sugar and Bence-Jones protein. A glucose tolerance test yielded the following results: Control, 95 mgm. per cent; 1/2 hour, 185; 1 hour, 200; 2 hours, $180 ; 3$ hours, $160 \mathrm{mgm}$. per cent. The serum cholesterol was $370 \mathrm{mgm}$. per cent, the serum calcium was 10.0 , inorganic phosphorus, $3.5 \mathrm{mgm}$. per cent, and chlorides, 120 m.eq. per $\mathrm{L}$. The blood urea $\mathrm{N}$ was 21 mgm. per cent. The blood phosphatase was $20 \mathrm{~K}-\mathrm{A}$ units. The basal metabolic rate was -16 per cent. Roentgenologic studies showed slight generalized decalcification of the skull and long bones. The sella turcica was normal. There was extensive decalcification of the entire spine with compression fractures of the 6 th, 8th, and 9th dorsal, and 1st lumbar vertebrae. There was, in addition, a transverse fracture through the left 7th rib in its axillary portion. Peri-renal insufflation failed to reveal any adrenal masses.

T. S. Female, age 18. During a period of 4 years prior to admission to the hospital, the patient developed marked facial and body hirsutism. One year before admission to the hospital, amenorrhea occurred, which has persisted. During the course of this past year there was a marked gain in weight. Physical examination revealed a very obese girl with a round plethoric face. There was a diffuse acneform eruption over the face and back. Many purplish striae were seen over the upper arms, breasts, and abdomen. Pelvic examination was negative. The blood pressure was 146/105. Urine was negative for sugar, and the basal metabolic rate was -19 per cent. The blood hemoglobin was 78 per cent, and the red blood cell count was 4.5 millions per c.mm. The glucose tolerance curve was as follows: Control, $75 \mathrm{mgm}$. per cent; 1/2 hour, 115; 1 hour, 170; 2 hours, 205; and 3 hours, $150 \mathrm{mgm}$. per cent. The serum calcium was 10.1, and the inorganic phosphorus, $2.5 \mathrm{mgm}$. per cent. The total serum proteins were 6.6 grams per cent. $\mathrm{X}$-ray of the sella turcica was normal. Both adrenals were explored, but no evidence of tumor masses was found.

J. S. Female, age 34. Suspected early Cushing's syndrome. One year prior to admission to the hospital, this patient noticed the gradual appearance of considerable facial hirsutism and a rapid and rather marked gain in weight. Her physician told her that she had developed hypertension. There were no irregularities in her menses, and no loss in sexual desire. On physical examination, she was found to be an obese woman with a round plethoric face. She had many non-violaceous striae over the lower abdomen and flanks. Pelvic examination was normal. The blood pressure was 140/100. The urine was negative, and the basal metabolic rate was -19 per cent. 
The glucose tolerance curve was as follows: Control, 65 mgm. per cent; $1 / 2$ hour, 100; 1 hour, 80; 2 hours, 70; and 3 hours, $65 \mathrm{mgm}$. per cent. The blood urea nitrogen was $9 \mathrm{mgm}$. per cent. The serum cholesterol was 225, cholesterol esters, 150, calcium, 10.6, inorganic phosphorus, $3.9 \mathrm{mgm}$. per cent, and chlorides, $106 \mathrm{~m}$.eq. per $\mathrm{L}$. The blood phosphatase was $5 \mathrm{~K}-\mathrm{A}$ units. The total serum proteins were 7.5 grams per cent. X-ray studies of the skull were normal, while the spine showed a slight generalized osteoporosis. Bilateral peri-renal insufflation failed to reveal any adrenal masses.

\section{SUMMARY}

(1) The utilization of intravenously injected salt, both before and after administration of desoxycorticosterone acetate, was studied in 12 normal individuals and in 4 patients with Cushing's syndrome.

(2) In normal individuals, the injection of hormone causes a decrease in the urinary excretion of sodium and chloride ions as compared to the control values.

(3) In the patients with Cushing's syndrome, the injection of desoxycorticosterone acetate re- sults in an increase in the urinary excretion of sodium and chloride ions.

(4) Various possible mechanisms are discussed which might explain this phenomenon.

(5) This test may be of value in the diagnosis of hyperfunction of the adrenal cortex.

\section{BIBLIOGRAPHY}

1. Kuhlmann, D., et al., Toxic effects of desoxycorticosterone esters in dogs. Science, 1939, 90, 496.

2. Ragan, C., et al., The syndrome of polydipsia and polyuria induced in normal animals by desoxycorticosterone acetate. Am. J. Physiol., 1940, 131, 73.

3. Mulinos, M. G., Spingarn, C. L., and Lojkin, M. E., A diabetes insipidus-like condition produced by small doses of desoxycorticosterone acetate in dogs. Am. J. Physiol., 1941, 135, 102.

4. Butler, A. M., and Tuthill, E., An application of the uranyl zinc acetate method for the determination of sodium in biological material. J. Biol. Chem., 1931, 93, 171.

5. Van Slyke, D. D., Determination of chlorides in blood and tissues. J. Biol. Chem., 1923, 58, 523.

6. Clinton, M., Jr., and Thorn, G. W., The effect of 11desoxy-17-hydroxy-corticosterone on renal excretion of electrolytes. Science, 1942, 96, 343. 